\title{
НОВЫЕ ИССЛЕДОВАНИЯ
}

\section{Оценка вклада интеллектуального капитала в создание ценности компании}

\author{
Березинец И.В. ${ }^{1}$, Удовиченко О.М. $^{2}$, Сысолятина Е.В. $^{3}$
}

В статье представлены результаты разработки системы показателей, позволяющих оценить вклад интеллектуального капитала в создание ценности компании. Для разработки данной методики оценивания вклада интеллектуального капитала (здесь и далее - ИК) в создание ценности компании были проанализированы основные системы измерения нематериальных активов, основанные на концепџии управления ценностью, определень драйверы создания иенности и их взаимосвязь с основными составляющими ИК, а также осуществлен отбор показателей, позволяющих оченить вклад ИК в достижение поставленных перед компанией целей, потенцииал ее развития и роста. Полученные оценки показателей представлены в виде рейтинговых икал как для отдельных видов и подвидов ИК, так и всего ИК в целом. В результате была получена модель, которая может служить ориентиром для менеджеров для анализа существующих проблем в управлении различными составляющими ИК и для повыщения его вклада в создание иенности компании.

$$
\text { JEL: G12, G31 }
$$

Ключевые слова: нематериальные активы, интеллектуальный капитал, ценность компании, система показателей эффективности деятельности.

\section{Введение}

В современном мире в условиях глобализации, развития интернет-технологий и усиления конкуренции фирмы ищут все новые способы формирования дополнительной ценности для потребителя, которые не могли бы быть легко скопированы конкурентами. Нематериальные активы, являющиеся по своей сути уникальными, как раз и способны приносить сверхприбыли, обеспечивать доминирующие конкурентные позиции или временное положение монополиста для компании.

Кроме того, нематериальные активы (здесь и далее по тексту - НМА) характеризуются возрастающим эффектом от масштаба, поскольку полезность идей, знаний и результатов исследований не подвержена закону убывающей отдачи, типичному для материальных активов. Способность к расширению и распространению нематериальных активов ограничивается только емкостью рынка.

Благодаря этим уникальным свойствам нематериальных активов измерение ценности интеллектуального капитала, его вклада в общую ценность компании, а также выработка способов управления им могут принести значительные выгоды компании. Но с другой стороны, именно нематериальные активы наиболее трудно поддаются оценке и измерению, а следовательно, и управлению.

Несмотря на то что существует множество разработанных схем и методик, по которым оцениваются различные составляющие ИК, единой, общепринятой схемы, как компаниям

\footnotetext{
${ }^{1}$ Канд. физ.-мат. наук, доцент кафедры финансов и учета Высшей школы менеджмента, СПбГУ.

${ }^{2}$ Канд. эконом.наук, доцент кафедры финансов и учета Высшей школы менеджмента, СПбГУ.

${ }^{3}$ Выпускница Высшей школы менеджмента, СПбГУ.
} 
оценивать, измерять, отражать в отчетности и управлять НМА, не существует. Это связано непосредственно с их свойствами - виртуальной природой, невозможностью отделить их для последующей продажи и уникальностью некоторых из них.

Поэтому данная статья посвящена построению системы показателей, которая бы позволила компании выявить и систематизировать виды НМА, используемых компанией, оценить вклад ИК в создание ценности компании. Предложенная методика позволит компании сфокусироваться на развитии наиболее перспективных видов интеллектуального капитала. Кроме того, проводя оценку вклада ИК в создание ценности компании, компания может выявить определенные проблемы, связанные с использованием того или иного актива. Затем, приняв определенные управленческие решения, компания может провести оценку НМА для того, чтобы понять, как изменилась его ценность. Сделать это будет несравнимо легче, когда в распоряжении компании будет подробная информация о видах ИК и их взаимосвязи с источниками создания ценности в компании.

Таким образом, данная статья дает представление о подходах к оценке и измерению ИК, о роли отдельных составляющих ИК в создании ценности компании и их оценке, а также о системе показателей для оценки вклада ИК в создание ценности компании. Разработанная система может быть использована в дальнейшем как в теоретических, так и в эмпирических исследованиях ИК, а также для организации реального управления ИК в компании.

\section{Определение интеллектуального капитала}

Существует множество работ, посвященных проблеме идентификации нематериальных активов и интеллектуального капитала. В целом можно выделить два основных подхода к определению ИК. Во-первых, бухгалтерский подход, согласно которому под интеллектуальным капиталом понимаются активы, не имеющие материальной формы, являющиеся результатом прошлых событий, которые могут быть измерены и которые приносят компании выгоды в будущем [IAS 38... 2009]. Во-вторых, более общий подход, который включает в состав нематериальных активов, помимо тех, что отражаются в финансовой отчетности, активы, которые не могут быть отражены в учете, но вносят значительный вклад в создание ценности в компании (например, знания сотрудников).

Следует отметить, что ряд авторов [Pike, Roos, Marr, 2005] разделяют понятия нематериальные активы и интеллектуальный капитал, но в данной работе будет использован другой подход [Lev, 2001; Stewart, 1997] согласно которому термины «нематериальные активы» (употребляется в финансовом учете), «запасы знаний» (экономическая теория) и «интеллектуальный капитал» (ИК) (управленческая и юридическая литература) употребляются как взаимозаменяемые.

Поскольку данная статья рассматривает оценку вклада отдельных элементов ИК в создание ценности компании вне зависимости от того, могут ли эти элементы найти свое отражение в бухгалтерском балансе, мы будем использовать следующее определение ИК: под интеллектуальным капиталом компании будут пониматься ресурсы и способности, стратегические по натуре, сложные для имитации и влияющие на формирование уникальных возможностей конкретной компании [Allee, 2008].

\section{Основные подходы к измерению и оценке ценности интеллектуального капитала}

При построении системы показателей для оценки вклада интеллектуального капитала в создание ценности компании, рассмотрим и проанализируем существующие методики измерения и оценки интеллектуального капитала и его вклада в создание ценности в компании. Традиционно выделяют две большие категории методов и подходов к измерению и оценке НМА - финансовые, базирующиеся на финансовых измерителях, и многокритериальные, которые используют помимо финансовых измерителей и другие 
показатели. Среди финансовых методов наиболее распространенными подходами являются:

- Методы прямого измерения интеллектуального капитала (Direct Intellectual Capital Methods - DIC). К данной категории могут быть отнесены все методы, позволяющие дать денежную оценку и достаточно точно идентифицировать отдельные нематериальные активы. Данная категория методов может быть применена, когда нематериальный актив имеет четко очерченные границы и, естественно, может быть объектом купли-продажи. Но данный подход неприменим для большинства нематериальных активов, которые не имеют четких границ и доступ к которым компания не может контролировать.

- Методы дохода/возврата на активы (Return on Assets Methods - ROA). Данная категория методов базируется на предположении, что «доходность материальных активов внутри отрасли относительно неизменна, поэтому разницу в доходности активов различных компаний можно объяснить наличием у них специфических нематериальных объектов». Таким образом, задача определения стоимости нематериальных активов состоит в определении этой дополнительной доходности. Так как в ходе данной оценки нет детализации измеряемых объектов, то ее результаты, скорее всего, не могут быть использованы для управления НМА.

- Методы рыночной капитализации (Market Capitalization Methods - MCM). B соответствии с данными методами, ценность интеллектуального капитала компании рассчитывается как разность между рыночной капитализацией компании и собственным капиталом. Данный класс методов имеет ряд ограничений по применению. Во-первых, он применим только к акциям тех компаний, которые котируются на рынке; во-вторых, не все нематериальные объекты непосредственно влияют на рыночную стоимость компании, так как эта стоимость определяется внешними инвесторами, которым порой неизвестно о существовании внутри компании уникальных бизнес-процессов, систем управления и т.д.; и в-третьих, данные методы также оценивают совокупность активов, так что они мало пригодны для принятия управленческих решений, касающихся конкретных НМА, и оценки отдельных активов для продажи.

К многокритериальным методам оценки относят методы системы показателей эффективности (Scorecard Methods - SC). Данные методы обладают тем преимуществом, что позволяют дать более полную характеристику НMA, измерить его с разных позиций. Методы системы показателей эффективности предназначены в основном для внутреннего использования - повышения эффективности использования ИК компании, мониторинга изменений в структуре ИК и т.д. Создаваемая модель оценки вклада интеллектуального капитала в создание ценности в компании относится к данному классу методов, поэтому необходимо провести анализ существующих моделей, позволяющих оценить ценность или вклад ИК в создание ценности в компании.

\section{Обзор многокритериальных систем измерения интеллектуального капитала}

Данные системы измерения НМА основаны на концепции управления ценностью (Value-based management) и предлагают довольно понятные и во многом схожие модели структуризации ИК. Все системы, кроме IC Monitor, используют деление ИК на три составляющие: человеческий капитал, организационный капитал, отношенческий (клиентский) капитал.

Что касается создания ценности в организации, то большинство моделей основано на том, что НМА являются основными источниками формирования ценности, и для того, чтобы построить качественную систему показателей для оценки ценности ИК, необходимо определить основные категории (источники ценности) ИК и как можно детальнее провести структуризацию по этим категориям на отдельные активы, а затем уже определиться с показателями (ключевыми факторами эффективности, индексами), измеряющими эти 
активы.

Следует отметить, что большинство систем показателей для оценки ценности ИК компании стараются объединить стратегический уровень управления компанией с операционным, подчеркивая необходимость связи между формированием показателей измерения НМА и стратегическими целями, стоящими перед компанией. Посредством такой связи менеджеры могут использовать полученную информацию о ИК в качестве измерения эффективности своей деятельности.

Таким образом, целью создания данных систем является не только измерение, но и последующее управление НМА внутри компании, как на стратегическом уровне, так и на операционном. Лишь одна модель, Scandia Navigator, создана специально для формирования отчетов для внешних пользователей. Данная модель является очень специфичной и не может применяться в других компаниях без существенных изменений и поправок.

Наиболее известные системы показателей для оценки ценности ИК, их краткая характеристика, основные достоинства и недостатки сгруппированы в таблице 1.

Таблица 1

Обзор систем показателей для оценки ценности ИК

\begin{tabular}{|c|c|c|c|}
\hline Вид модели & Oписание & Достоинства & Недостатки \\
\hline Scandia Navigator & $\begin{array}{l}\text { Данная система } \\
\text { измерения помогает } \\
\text { компании построить } \\
\text { универсальный отчет о } \\
\text { эффективности } \\
\text { использования ИК на } \\
\text { основе создания } \\
\text { индексов, которые } \\
\text { оценивают отдельные } \\
\text { элементы ИК }\end{array}$ & $\begin{array}{l}\text { 1) Большой } \\
\text { охват } \\
\text { показателей } \\
\text { измерения } \\
\text { структурного и } \\
\text { клиентского } \\
\text { капитала }\end{array}$ & $\begin{array}{l}\text { 1) Не может быть } \\
\text { применена в другой } \\
\text { отрасли и для другой } \\
\text { компании } \\
\text { 2) Показатели } \\
\text { рассчитываются на } \\
\text { основе отчетности, } \\
\text { поэтому } \\
\text { некоторые из них не } \\
\text { отражают создание } \\
\text { ценности }\end{array}$ \\
\hline Balanced scorecard & $\begin{array}{l}\text { Измерение стоимости } \\
\text { нематериальных } \\
\text { активов подразумевает } \\
\text { оценку степени их } \\
\text { соответствия стратегии } \\
\text { компании. Сначала } \\
\text { разрабатывается } \\
\text { стратегическая карта, } \\
\text { затем в данную систему } \\
\text { вписываются } \\
\text { нематериальные активы } \\
\text { и определяется } \\
\text { стратегическая } \\
\text { готовность групп ИК } \\
\text { путем измерения } \\
\text { различных показателей }\end{array}$ & $\begin{array}{l}\text { 1) Связь } \\
\text { показателей со } \\
\text { стратегическими } \\
\text { целями } \\
\text { 2) Четкие связи } \\
\text { между } \\
\text { стратегическими } \\
\text { целями и } \\
\text { факторами } \\
\text { успеха } \\
\text { (драйверами } \\
\text { ценности) }\end{array}$ & $\begin{array}{l}\text { 1) Границы четырех } \\
\text { перспектив } \\
\text { рассматриваются } \\
\text { изолированно } \\
\text { 2) Внешняя перспектива } \\
\text { фокусируется только на } \\
\text { клиентах, не охватывает } \\
\text { всех стейкхолдеров } \\
\text { 3) Нет различия между } \\
\text { факторами человеческого } \\
\text { и структурного капитала }\end{array}$ \\
\hline IC Index & $\begin{array}{l}\text { Позволяет определить } \\
\text { изменение ценности } \\
\text { ИК посредством } \\
\text { составления индексов } \\
\text { для его ключевых } \\
\text { групп, а также выразить }\end{array}$ & $\begin{array}{l}\text { 1) Причинно- } \\
\text { следственные } \\
\text { связи между } \\
\text { показателями и } \\
\text { стратегией } \\
\text { 2) Гибкость и } \\
\end{array}$ & $\begin{array}{l}\text { 1) Специфичность и } \\
\text { ограниченность } \\
\text { применения модели } \\
\text { 2) Неустойчивость } \\
\text { показателей } \\
\text { 3) Высокая } \\
\end{array}$ \\
\hline
\end{tabular}




\begin{tabular}{|c|c|c|c|}
\hline & $\begin{array}{l}\text { все показатели в } \\
\text { индексах (построить } \\
\text { единую систему } \\
\text { измерений) }\end{array}$ & динамичность & $\begin{array}{l}\text { субъективность при } \\
\text { определении весов и } \\
\text { показателей }\end{array}$ \\
\hline IC Monitor & $\begin{array}{l}\text { Происходит измерение } \\
\text { эффективности } \\
\text { использования НМА в } \\
\text { компании за счет } \\
\text { выделения критериев } \\
\text { эффективности и } \\
\text { параметров, } \\
\text { соответствующих } \\
\text { каждому критерию }\end{array}$ & $\begin{array}{l}\text { 1) Выбор } \\
\text { показателей } \\
\text { основывается на } \\
\text { стратегии и } \\
\text { ориентируется } \\
\text { на } \\
\text { экономическую } \\
\text { эффективность } \\
\text { и рост }\end{array}$ & $\begin{array}{l}\text { 1) Нет связи между } \\
\text { финансовыми } \\
\text { показателями и } \\
\text { показателями, } \\
\text { используемыми в модели }\end{array}$ \\
\hline
\end{tabular}

Исходя из приведенной выше таблицы, можно сделать вывод о том, что ни одна система показателей оценки ценности ИК не лишена недостатков. Для того чтобы система показателей была эффективной, она должна обладать следующими свойствами:

1. Она должна давать достоверные результаты.

2. Ее построение должно быть основано на доступных данных.

3. По результатам проводимой на ее основе оценки будет возможно принимать управленческие решения, направленные на повышение ценности компании.

4. Разработанная система должна позволять проводить сравнение результатов с компаниями-конкурентами.

5. Система должна быть надежная и динамичная.

6. Затраты времени и человеческих ресурсов для создания системы не должны превышать тех выгод, которые они приносят для компании [Andreou, Green and Stankosky, 2007].

Отвечать всем перечисленным выше свойствам не может ни одна система показателей, но эти свойства должны служить ориентирами при построении новой системы. Особенно это касается достоверности и реалистичности результатов, а также того, что данная система должна органично вписываться в систему принятия решений, направленных на повышение ценности компании. Кроме того, компании важно понять, какие именно составляющие ИК создают ее ценность, поэтому организации необходимо иметь четкую наглядную структуру нематериальных активов, а затем установить связи между НМА, драйверами создания ценности и результатами деятельности компании.

При построении такой системы показателей также очень важным является выбор показателей измерения: они должны быть релевантными, отражать ценность того нематериального актива, который они представляют, должны быть пригодными для сравнения. Немаловажным фактором успешности показателя служит и то, насколько просто он вычисляется, нужны ли дополнительные расходы для получения необходимой для его расчета информации. Очевидно, что лучше использовать относительные показатели, которые обеспечат сравнимость результатов измерения.

Что касается целей, которые компания может ставить перед собой при создании и внедрении модели оценки вклада ИК в создание ценности компании, то они могут быть разделены на внешние и внутренние. Формирование отчетности для внешнего пользователя отвечает первому типу целей. К внутренним целям относится создание системы управления знаниями (система показателей оценки вклада НМА как составной части управления знаниями в организации), оценка отдачи на вложенный капитал в нематериальные активы, улучшение качества продуктов и услуг для потребителя, развитие инновационной деятельности, создание обучающейся организации и т.д.

Проблемы с построением систем измерения ИК, ориентированных на внешнего пользователя, связаны с тем, что, несмотря на растущую тенденцию раскрытия информации 
о НMA, существует проблема с возможностью сравнения такой отчетности у разных компаний. На сегодняшний момент данная проблема не может быть решена полностью, и основной задачей тех фирм, которые публикуют дополнительно информацию о некоторых составляющих интеллектуального капитала, является желание показать инвесторам и внешним пользователям, насколько они конкурентоспособны и какой потенциал роста и развития имеют.

В данной статье описываются принципы построения системы показателей и сами показатели, используемые для оценки вклада ИК в создание ценности компании. Разрабатываемая система должна предоставлять достоверные и реалистичные результаты, быть надежной, устанавливать связь отдельных составляющих ИК с созданием ценности в организации, а также служить основой для определения наиболее значимых для создания ценности нематериальных активов. Система показателей ориентирована на внутреннего пользователя и должна способствовать решению оперативных и стратегических задач. Она предназначена для компаний, основу конкурентного преимущества которых составляют именно нематериальные активы.

\section{Построение системы показателей оценки вклада интеллектуального капитала в создание ценности компании}

\section{Определение драйверов создания ценности в соответствии со структурой ИК}

Как уже отмечалось, для построения данной системы показателей необходимо определить структуру ИК, которая соответствует созданию ценности в организации, и предложить такую классификацию показателей, которые помогут компании определить, какие нематериальные ресурсы являются наиболее важными в создании ценности, а также оценить их вклад в создание этой ценности.

Таким образом, алгоритм работы при построении системы показателей для оценки вклада интеллектуального капитала в создание ценности компании будет следующим:

1. Определение ключевых драйверов создания ценности.

2. Определение взаимосвязи между драйверами создания ценности и ключевыми составляющими ИК.

3. Выявление показателей по заранее определенным категориям НМА, которые связаны с созданием ценности в компании.

4. Классификация данных показателей на показатели экономической и управленческой эффективности, потенциала развития и роста и определение целевых значений по каждому показателю.

5. Построение рейтинговых шкал и определение рейтинга по каждому виду показателей для каждой составляющей ИК.

6. Выработка управленческих решений, направленных на увеличение вклада интеллектуального капитала для конкретной компании.

Перед тем как идентифицировать драйверы создания ценности в компании, необходимо дать определение ценности бизнеса. Следует различать понятия стоимости и ценности. Обычно говорят о стоимости в контексте купли/продажи бизнеса, как о неких расходах, которые компания несет при покупке. Экономическая ценность лежит в основе стоимости, являясь исходной категорией по отношению к ней. При определении ценности, создаваемой компанией, необходимо учитывать не только расходы на ее создание и выгоды, получаемые компанией, но и альтернативные издержки привлечения капитала [Коупленд, Коллер, Муррин, 2005].

Под драйверами создания ценности обычно понимают источники создания ценности в компании. Следует отметить, что разные авторы понимают под источниками создания ценности нематериальные активы или ресурсы (ресурсный подход) [Pike, Fernström, Roos, 2005, p. 489], ключевые компетенции компании [Pike, Fernström, Roos, 2005, p. 489], или 
стейкхолдеров (в основном клиентов, поставщиков и партнеров) [Green, Ryan, 2005, p. 43]. Наиболее полным определением, касающимся драйверов ценности, является подход Грин [Green, 2005], в котором выделяется 8 основных драйверов ценности:

1. Клиенты - создают экономическую ценность за счет отношений (лояльность, удовлетворенность, долговечность), которые строятся между компанией и потребителем.

2. Конкуренты - создают экономическую ценность за счет позиционирования компании (репутация, доля на рынке, узнаваемость бренда, имидж) на рынке.

3. Сотрудники - создают экономическую ценность за счет коллективных способностей (знания, навыки, компетенции, ноу-хау) сотрудников компании.

4. Информация - создает экономическую ценность за счет способности компании собирать и предоставлять необходимую информацию и знания в нужной форме, нужным людям и в нужное время

5. Партнеры - создают экономическую ценность за счет связей (финансовых, стратегических, силовых), которые компания установила с другими организациями и людьми (консультанты, потребители, поставщики, конкуренты, партнеры) для достижения поставленных перед ней целей.

6. Процессы - создают экономическую ценность за счет способности компании (правила, процедуры, методы, техники) влиять на способы работы и создания ценности для стейкхолдеров.

7. Продукты/услуги - создают экономическую ценность за счет способности компании создавать и продвигать свои продукты и услуги, которая отражает ее понимание рынка и желания и требования потребителей.

8. Технологии - создают экономическую ценность за счет внедрения различных способов и инструментов организации бизнеса, в которые компания инвестирует средства для поддержки своей текущей деятельности, менеджмента и будущего развития.

Эти драйверы создания ценности напрямую связаны с созданием различных составляющих ИК компании. Для того чтобы проследить эту связь, рассмотрим принятую в данной работе классификацию интеллектуального капитала [Volkov, Garanina, 2007]. В соответствии с этой классификацией, интеллектуальный капитал делился на три ключевые составляющие:

- Человеческий капитал - способность компании получать выгоды от знаний, навыков и опыта работников, которые обычно принадлежат последним.

- Отношенческий капитал - способность компании получать выгоды от ресурсов, связанных с внешними взаимоотношениями компании (с потребителями, поставщиками и т.д.).

- Организационный капитал - способность компании получать выгоды от знаний, остающихся внутри компании. Такие знания могут относиться к интеллектуальной собственности и к инфраструктурным активам.

В свою очередь различные НМА, входящие в организационный капитал, можно разделить на два подвида: инновационный капитал и процессный капитал. Под инновационным капиталом будем понимать способность компании получать экономические выгоды от создания новых продуктов или услуг и их продвижения на рынке. В данную категорию, помимо других НМА, будет входить вся интеллектуальная собственность компании (патенты, торговые марки, лицензии и т.д.).

Другим подвидом организационного капитала является процессный капитал, под которым будем понимать способность компании получать экономические выгоды от управления информационными системами, бизнес-процессами и применяемыми в организации информационными технологиями. К этой категории будут относиться различные инфраструктурные активы компании: организационная культура, организация бизнес-процессов, принятые практики управления бизнесом и т.д. 
Отношенческий капитал также можно разделить на два подвида: клиентский капитал и социальный капитал. Такое деление целесообразно, так как, во-первых, компания напрямую взаимодействует и формирует особые отношения именно с клиентами/ потребителями; вовторых, именно от потребителей зависит благосостояние компании, и именно они являются основными источниками получения выручки для организации. Под клиентским капиталом будем понимать способность компании получать экономические выгоды от взаимоотношений, построенных с клиентами. В данную категорию будут входить следующие НМА: лояльность потребителей к компании и бренду, удовлетворенность потребителей продуктами и услугами, предоставляемыми компанией, и т.д. Под социальным капиталом понимается способность компании получать экономические выгоды от правильного позиционирования компанией себя на рынке, а также от установления связей с основными заинтересованными лицами (за исключением клиентов). К данному виду капитала будут относиться такие НМА, как репутация компании, имидж и узнаваемость бренда, а также способность извлекать выгоды от участия в стратегических альянсах, партнерствах и т.д.

Отметим, что данные драйверы ценности, как и составляющие ИК, не находятся в статичном состоянии, а взаимодействуют друг с другом. Многие авторы утверждают, что именно сочетание ресурсов обеспечивает уникальность и ценность создаваемых продуктов или услуг в компании, и с ними нельзя не согласиться. Но в то же самое время структуризация ИК необходима для проведения более глубокого анализа и лучшего измерения вклада нематериальных активов, участвующих в создании ценности компании.

Таким образом, было выделено восемь типов драйверов создания ценности в организации и определены их связи с различными составляющими ИК. Далее рассмотрим третий и четвертый этапы построения системы - выявление показателей по заранее определенным факторам успеха использования ИК и осуществление классификации выявленных показателей.

\section{Отбор показателей для измерения отдельных составляющих ИК и их структуризация}

Перед тем как начать отбор показателей, которые позволяют дать оценку вклада отдельных составляющих ИК в создание ценности в компании, необходимо выделить факторы успеха использования различных НМА. Таким образом, для каждого вида нематериальных активов будут выделены такие факторы и уже затем будут определены показатели, позволяющие оценить способность компании создавать ценность.

В общем виде взаимосвязи между драйверами ценности, отдельными составляющими ИК, а также факторами успеха использования ИК представлены в таблице 2.

Таблица 2

Категории интеллектуального капитала и драйверы создания ценности

\begin{tabular}{|c|c|c|c|c|c|}
\hline & \multicolumn{5}{|c|}{ Интеллектуальный капитал } \\
\hline Категории ИК & $\begin{array}{l}\text { Человеческий } \\
\text { капитал }\end{array}$ & Организационны & капитал & Отношенческий & капитал \\
\hline Подвиды ИК & & $\begin{array}{l}\text { Инновационный } \\
\text { капитал }\end{array}$ & $\begin{array}{l}\text { Процессный } \\
\text { капитал }\end{array}$ & $\begin{array}{l}\text { Клиентский } \\
\text { капитал }\end{array}$ & $\begin{array}{l}\text { Социальный } \\
\text { капитал }\end{array}$ \\
\hline $\begin{array}{l}\text { Драйверы } \\
\text { ценности }\end{array}$ & Сотрудники & Продукт/услуга & $\begin{array}{l}\text { Технологии, } \\
\text { процессы, } \\
\text { информация }\end{array}$ & Клиенты & $\begin{array}{l}\text { Конкуренты, } \\
\text { партнеры }\end{array}$ \\
\hline $\begin{array}{l}\text { Факторы } \\
\text { успеха } \\
\text { использования } \\
\text { ИК }\end{array}$ & $\begin{array}{l}\text { Лидерские } \\
\text { качества } \\
\text { сотрудников, } \\
\text { профессионализм } \\
\text { сотрудников, } \\
\text { результативность }\end{array}$ & $\begin{array}{l}\text { Инновационный } \\
\text { потенциал, } \\
\text { успешность } \\
\text { реализации } \\
\text { инновационных } \\
\text { идей }\end{array}$ & $\begin{array}{l}\text { Управление } \\
\text { информацией, } \\
\text { налаженность } \\
\text { и гибкость } \\
\text { бизнес } \\
\text { процессов, }\end{array}$ & $\begin{array}{l}\text { Лояльность } \\
\text { клиентов, } \\
\text { прибыльность, } \\
\text { налаженность } \\
\text { обратной } \\
\text { связи с }\end{array}$ & $\begin{array}{l}\text { Конкурентоспосо } \\
\text { бность компании, } \\
\text { надежность } \\
\text { партнера, } \\
\text { налаженность } \\
\text { связей со }\end{array}$ \\
\hline
\end{tabular}




\begin{tabular}{|l|l|l|l|l|}
\hline & $\begin{array}{l}\text { сотрудников, } \\
\text { вовлеченность } \\
\text { адаптация, } \\
\text { эффективность } \\
\text { HR-службы }\end{array}$ & $\begin{array}{l}\text { возможность } \\
\text { обновления } \\
\text { технологий }\end{array}$ & клиентом & стейкхолдерами \\
\hline
\end{tabular}

Кроме того, отобранные показатели, измеряющие ценность НМА для компании, классифицируются на показатели, характеризующие:

- Управленческую эффективность - отбираются показатели, позволяющие измерить степень выполнения поставленных перед компанией целей, а также характеризующие результаты создания ценности в организации.

- Экономическую эффективность - отбираются показатели, которые характеризуют риски, связанные с использованием HМA, а также позволяющие измерить рентабельность и оправданность инвестиций в отдельные составляющие ИК.

- Потенциал роста и развития - отбираются показатели, позволяющие измерить потенциал создания ценности в компании за счет инвестиций и управления HМА.

Отметим также, что показатели, определяющие экономическую эффективность, характеризуют прошлые действия компании, управленческую эффективность - действия в настоящий момент, а потенциал роста и развития - будущее использование ИК.

Показатели управленческой эффективности и потенциала роста и развития нефинансовые. С целью их измерения оценка каждого показателя производится по десятибалльной шкале респондентами анкеты, составленной для измерения приведенных выше показателей. Основными респондентами данной анкеты являются различные группы сотрудников, клиентов и партнеров компании. Проблема заключается в том, что, несмотря на применение шкальных оценок, данные показатели являются субъективными и отражают мнение людей, которые отвечают на вопросы. Для того чтобы эти показатели реально отражали существующую ситуацию в компании, следует проводить опрос среди сотрудников, которые участвуют в создании ценности в организации и могут дать компетентную оценку деятельности компании.

Помимо проведения анкетирования, в котором опрашиваемые сотрудники должны по десятибалльной шкале измерить показатели, для некоторых показателей проводится количественная оценка, которая также позволяет оценить вклад ИК в создание ценности компании.

После обработки результатов опроса баллы переводятся в рейтинги. Таким образом, на стратегическом уровне компания получает рейтинг эффективности и потенциала использования своего ИК в целом и отдельных его составляющих. На операционном уровне менеджеры могут увидеть реальные баллы показателей по критическим факторам успеха использования НМА, выявить реальные проблемы в управлении НМА и принять соответствующие меры.

Что касается показателей экономической эффективности, то они являются финансовыми, и для их расчета используется информация из финансовых отчетов компании. К тому же в данной модели используются в основном относительные показатели, а затем происходит сравнение этих показателей с соответствующими им значениями в предыдущем периоде. Затем положительным изменениям присваивается положительный рейтинг, а отрицательным - отрицательный.

Следует отметить, что не для всех критических факторов успеха можно выделить экономические показатели (это связано со спецификой нематериальных активов - они могут быть не связаны напрямую с созданием ценности в организации, или просто не иметь финансового выражения).

Теперь, когда определены основы для классификации показателей, рассмотрим отдельно показатели для каждого подвида интеллектуального капитала. 


\section{Показатели оценки вклада человеческого капитала (здесь и далее - ЧК) в создание ценности в компании}

ЧК вносит существенный вклад в создание ценности любой организации и непосредственно воздействует на улучшение таких показателей, как производительность, качество обслуживания и удовлетворение потребителя, удовлетворенность сотрудников своей работой, результативность, которые, в свою очередь, выливаются в улучшение финансовых показателей компании - прибыльность, ценность для акционеров и т.д. Для определения этого вклада можно выделить следующие критические факторы успеха использования ЧК:

- Развитие лидерских качеств - способности того, кто управляет, координирует и планирует работу компании в целом, ее отдела или бизнес-единицы вести организацию к достижению поставленных целей.

- Профессионализм сотрудников - опыт, знания, уровень образования и способностей сотрудников в организации.

- Результативность работы сотрудников - способность сотрудников применять свои знания, опыт и способности для достижения поставленных целей. Очень важный фактор для создания ценности в организации, так как у сотрудников должны быть все условия для реализации их идей.

- Вовлеченность - эмоциональное участие и приверженность сотрудников их работе и организации. Высокая текучесть персонала, например, влечет за собой высокие издержки по найму, тренингам и развитию персонала и будет свидетельствовать о низкой вовлеченности.

- Адаптация - определяет способность сотрудников гибко реагировать на изменяющиеся бизнес-условия, а также определяет, насколько развита в компании система оказания помощи в адаптации для новых сотрудников.

- Эффективность HR-службы - способность компании эффективно (экономическая и управленческая эффективность) управлять человеческими ресурсами.

Исходя из приведенных выше рассуждений, можно сгруппировать показатели оценки вклада человеческого капитала в создание ценности компании в следующей таблице.

Таблица 3

Показатели оценки вклада человеческого капитала в создание ценности компании

\begin{tabular}{|l|l|l|l|}
\hline $\begin{array}{l}\text { Факторы успеха } \\
\text { использования } \\
\text { человеческого } \\
\text { капитала }\end{array}$ & $\begin{array}{l}\text { Показатели } \\
\text { Эффективность }\end{array}$ & $\begin{array}{l}\text { Экономическая } \\
\text { эффективность }\end{array}$ & $\begin{array}{l}\text { Потенциал развития } \\
\text { и роста }\end{array}$ \\
\hline Лидерство & $\begin{array}{l}\text { Способность } \\
\text { вдохновлять } \\
\text { сотрудников на } \\
\text { достижение } \\
\text { поставленных задач } \\
\text { заставленный } \\
\text { период }\end{array}$ & $\begin{array}{l}\text { Применение } \\
\text { тренингов на } \\
\text { развитие лидерства у } \\
\text { сотрудников }\end{array}$ \\
\hline Профессионализм & $\begin{array}{l}\text { Уровень } \\
\text { профессионального } \\
\text { развития } \\
\text { сотрудников }\end{array}$ & $\begin{array}{l}\text { Потенциал для } \\
\text { профессионального } \\
\text { роста у молодых } \\
\text { сотрудников }\end{array}$ \\
\hline Результативность & $\begin{array}{l}\text { Процент новых идей, } \\
\text { предложенных }\end{array}$ & $\begin{array}{l}\text { Доля прибыли, } \\
\text { приходящаяся на }\end{array}$ & $\begin{array}{l}\text { Уровень участия } \\
\text { сотрудников в }\end{array}$ \\
\hline
\end{tabular}




\begin{tabular}{|c|c|c|c|}
\hline & $\begin{array}{l}\text { сотрудниками и } \\
\text { удачно } \\
\text { реализованных }\end{array}$ & сотрудника & $\begin{array}{l}\text { профессиональных } \\
\text { конкурсах, } \\
\text { конференциях и т.п. }\end{array}$ \\
\hline Вовлеченность & $\begin{array}{l}\text { Рабочая атмосфера в } \\
\text { компании, } \\
\text { лояльность, } \\
\text { способность } \\
\text { удерживать } \\
\text { ключевых } \\
\text { сотрудников } \\
\end{array}$ & Текучесть персонала & $\begin{array}{l}\text { Возможность } \\
\text { свободного } \\
\text { выражения идей }\end{array}$ \\
\hline Адаптация & $\begin{array}{l}\text { Способность } \\
\text { сотрудников быстро } \\
\text { реагировать на } \\
\text { изменения во } \\
\text { внешней среде, } \\
\text { уровень } \\
\text { сопротивления } \\
\text { изменениям, } \\
\text { проводимым в } \\
\text { компании }\end{array}$ & & $\begin{array}{l}\text { Уровень } \\
\text { организации систем } \\
\text { адаптации для } \\
\text { нового сотрудника }\end{array}$ \\
\hline $\begin{array}{l}\text { Эффективность } \\
\text { службы HR }\end{array}$ & $\begin{array}{l}\text { Положительный } \\
\text { имидж на рынке } \\
\text { труда, } \\
\text { удовлетворенность } \\
\text { сотрудников } \\
\text { системой поощрения } \\
\text { и условиями работы }\end{array}$ & $\begin{array}{l}\text { Доля инвестиций в } \\
\text { управление } \\
\text { персоналом в } \\
\text { выручке компании, } \\
\text { текучесть персонала }\end{array}$ & $\begin{array}{l}\text { Применение новых } \\
\text { практик управления } \\
\text { персоналом: } \\
\text { индивидуальные } \\
\text { планы развития } \\
\text { сотрудников, } \\
\text { проведение оценки } \\
\text { деятельности } \\
\text { сотрудников, } \\
\text { обеспечение } \\
\text { обратной связи } \\
\end{array}$ \\
\hline
\end{tabular}

\section{Показатели оценки вклада инновационного капитала в создание ценности}

Инновационный капитал компании непосредственно определяет конкурентоспособность организации на рынке, так как постоянное совершенствование качества существующих продуктов и создание новых определяет интерес к компании со стороны потребителей и заставляет их оставаться с компанией.

Таким образом, наиболее важными факторами успеха использования инновационного капитала в создании ценности компании будут следующие факторы:

- Развитие инновационного потенциала характеризует потенциальные возможности компании создавать новые продукты и услуги.

- Способность к реализации инновационных идей характеризует реально созданные продукты и услуги или их усовершенствованные версии и их успешность на рынке доходы, получаемые компанией от создания новых продуктов или услуг.

Показатели, применяемые в данной модели и относящиеся к оценке вклада инновационного капитала в создание ценности компании, сведены в следующей таблице. 
Показатели оценки вклада инновационного капитала в создание ценности компании

\begin{tabular}{|c|c|c|c|}
\hline \multirow{2}{*}{$\begin{array}{l}\text { Факторы успеха } \\
\text { использования } \\
\text { инновационного } \\
\text { капитала }\end{array}$} & \multicolumn{3}{|c|}{ Показатели } \\
\hline & $\begin{array}{l}\text { Управленческая } \\
\text { эффективность }\end{array}$ & $\begin{array}{l}\text { Экономическая } \\
\text { эффективность }\end{array}$ & $\begin{array}{l}\text { Потенциал развития } \\
\text { и роста }\end{array}$ \\
\hline $\begin{array}{l}\text { Развитие } \\
\text { инновационного } \\
\text { потенциала }\end{array}$ & $\begin{array}{l}\text { Развитие } \\
\text { инновационно- } \\
\text { творческих } \\
\text { процессов в } \\
\text { компании } \\
\end{array}$ & $\begin{array}{l}\text { Доля R\&D } \\
\text { инвестиций в } \\
\text { выручке }\end{array}$ & $\begin{array}{l}\text { Наличие наукоемкой } \\
\text { базы }\end{array}$ \\
\hline $\begin{array}{l}\text { Реализация } \\
\text { инновационных } \\
\text { идей }\end{array}$ & $\begin{array}{l}\text { Уровень внедрения } \\
\text { новых идей в } \\
\text { компании }\end{array}$ & $\begin{array}{l}\text { Доля выручки, } \\
\text { приходящаяся на } \\
\text { новые } \\
\text { продукты/услуги }\end{array}$ & $\begin{array}{l}\text { Возможности } \\
\text { реализации всех } \\
\text { потенциально } \\
\text { успешных идей }\end{array}$ \\
\hline
\end{tabular}

\section{Показатели оценки вклада процессного капитала в создание ценности компании}

Процессный капитал (способность компании получать экономические выгоды от управления информационными системами, бизнес-процессами и применяемыми в организации ИТ) играет значительную роль в создании ценности компании, так как осуществляет роль передатчика информации и знаний в ней, а также определяет, как организована работа в компании. Данный вид капитала может быть охарактеризован следующими факторами успеха:

- Развитие информационного капитала характеризует способность компании собирать и своевременно передавать знания и информацию. Данную категорию могут характеризовать процент провалившихся бизнес-решений из-за не предоставленной вовремя информации, стоимость неудачных бизнес-решений, процент достигнутых успешных стратегических целей, среднее время, необходимое для обмена информацией внутри организации.

- Налаженность бизнес-процессов определяется наличием сбоев в системе управления. Поэтому показателями в данном случае могут быть процент проектов, завершенных в срок и в соответствии с принятыми стандартами качества в компании, а также процент случаев, когда ключевые ресурсы были доступны вовремя.

- Обновление технологий характеризует то, насколько компания использует передовые технологии для повышения эффективности повседневной работы. Примеры показателей: затраты на внедрение новых технологий в сравнении с прибылью, которую они принесут, эффективность использования оборудования и ИТ (производительность и используемая мощность оборудования, уровень дефектов, уровень соответствия используемых ИТ поставленным стратегическим целям в компании).

Таблица 5

Показатели оценки вклада процессного капитала в создание ценности компании

\begin{tabular}{|l|l|l|l|}
\hline $\begin{array}{l}\text { Факторы успеха } \\
\text { использования } \\
\begin{array}{l}\text { процессного } \\
\text { капитала }\end{array}\end{array}$ & $\begin{array}{l}\text { Управленческая } \\
\text { эффективность }\end{array}$ & $\begin{array}{l}\text { Экономическая } \\
\text { эффективность }\end{array}$ & $\begin{array}{l}\text { Потенциал развития } \\
\text { и роста }\end{array}$ \\
\hline $\begin{array}{l}\text { Информационный } \\
\text { капитал }\end{array}$ & $\begin{array}{l}\text { Способность } \\
\text { компании быстро и }\end{array}$ & $\begin{array}{l}\text { Возможности } \\
\text { внедрения новых }\end{array}$ \\
\hline
\end{tabular}




\begin{tabular}{|c|c|c|c|}
\hline & $\begin{array}{l}\text { вовремя передавать } \\
\text { информацию }\end{array}$ & & $\begin{array}{l}\text { систем обмена } \\
\text { информацией в } \\
\text { компании } \\
\text { (использование } \\
\text { интранета, } \\
\text { неформальные } \\
\text { системы } \\
\text { коммуникаций и } \\
\text { т.д.) }\end{array}$ \\
\hline $\begin{array}{l}\text { Налаженность } \\
\text { бизнес-процессов }\end{array}$ & $\begin{array}{l}\text { Время, необходимое } \\
\text { для ответа на новые } \\
\text { запросы клиентов } \\
\text { (качество } \\
\text { обслуживания), } \\
\text { скорость адаптации } \\
\text { бизнес-процессов к } \\
\text { изменяющимся } \\
\text { условиям во } \\
\text { внешней среде, } \\
\text { степень доступности } \\
\text { ресурсов, } \\
\text { необходимых для } \\
\text { производства } \\
\text { продукции }\end{array}$ & $\begin{array}{l}\text { Коэффициент } \\
\text { оборачиваемости } \\
\text { запасов, изменения } \\
\text { операционного } \\
\text { цикла компании }\end{array}$ & $\begin{array}{l}\text { Уровень } \\
\text { организации } \\
\text { контроля за } \\
\text { качеством }\end{array}$ \\
\hline $\begin{array}{l}\text { Управление } \\
\text { технологиями }\end{array}$ & $\begin{array}{l}\text { Уровень внедрения } \\
\text { и использования } \\
\text { современных } \\
\text { технологий в } \\
\text { компании }\end{array}$ & $\begin{array}{l}\text { Доля инвестиций в } \\
\text { ИТ в выручке } \\
\text { компании }\end{array}$ & $\begin{array}{l}\text { Уровень обновления } \\
\text { технологий }\end{array}$ \\
\hline
\end{tabular}

\section{Показатели оценки вклада клиентского капитала в создание ценности}

Клиентский капитал представляет собой экономическую ценность, которая является результатом связей (лояльность, удовлетворенность), которые организация выстраивает со своими потребителями товаров и услуг. Ключевыми факторами успеха использования клиентского капитала в создании ценности компании являются:

- Лояльность потребителей - измеряет вероятность того, что потребитель вернется к компании после покупки продукта/услуги. Уровень удержания потребителей, например, будет релевантным показателем в данном случае.

- Прибыльность - характеризует прибыль, которую приносят потребители, позволяет определить наиболее важных клиентов для компании. Например, издержки приобретения нового потребителя в сравнении с доходом, который он принесет в будущем или уже принес, показатель чистого дохода на потребителя, надбавка к цене, которую потребители готовы заплатить.

- Налаженность обратной связи с потребителями - характеризует скорость реагирования на запросы потребителя. Пример показателей: количество успешных предложений от потребителей, которые помогли улучшить существующие процессы в организации или создать/улучшить продукт или услугу. 
Таблица 6

Показатели оценки вклада клиентского капитала в создание ценности компании

\begin{tabular}{|c|c|c|c|}
\hline \multirow{2}{*}{$\begin{array}{l}\text { Факторы успеха } \\
\text { использования } \\
\text { клиентского } \\
\text { капитала }\end{array}$} & \multicolumn{3}{|c|}{ Показатели } \\
\hline & $\begin{array}{l}\text { Управленческая } \\
\text { эффективность }\end{array}$ & $\begin{array}{l}\text { Экономическая } \\
\text { Эффективность }\end{array}$ & Потенциал развития \\
\hline Лояльность & $\begin{array}{l}\text { Уровень удержания } \\
\text { потребителей, } \\
\text { удовлетворенность } \\
\text { потребителей }\end{array}$ & & $\begin{array}{l}\text { Доля потребителей, } \\
\text { готовых } \\
\text { рекомендовать } \\
\text { компанию своим } \\
\text { друзьям и знакомым }\end{array}$ \\
\hline Прибыльность & & $\begin{array}{l}\text { Затраты на } \\
\text { приобретение } \\
\text { нового потребителя, } \\
\text { прибыль, которую } \\
\text { приносит крупный } \\
\text { клиент, прирост } \\
\text { объема продаж, доля } \\
\text { инвестиций в } \\
\text { маркетинг в выручке }\end{array}$ & $\begin{array}{l}\text { Возможности } \\
\text { расширения рынка } \\
\text { сбыта, выхода на } \\
\text { новые рынки }\end{array}$ \\
\hline Обратная связь & $\begin{array}{l}\text { Уровень успешности } \\
\text { предложений от } \\
\text { потребителя }\end{array}$ & & $\begin{array}{l}\text { Развитие системы } \\
\text { взаимодействия с } \\
\text { клиентом, } \\
\text { потребителем и } \\
\text { организации } \\
\text { обратной связи }\end{array}$ \\
\hline
\end{tabular}

\section{Показатели оценки вклада социального капитала в создание ценности компании}

Выделяют следующие категории показателей оценки вклада социального капитала в создание ценности компании:

- Конкурентоспособность характеризуется имиджем бренда, уровнем положительной информации о компании в прессе, уровнем качества продуктов или услуг в сравнении со среднеотраслевым уровнем (по мнению основных потребителей).

- Надежность партнера характеризуется такими показателями, как, например, среднее время, необходимое поставщику для поставки ресурсов, и в непредвиденных случаях (частота срыва или задержек поставок) вовлеченность партнера в бизнес компании (теснота связей между поставщиком и компанией).

- Налаженность связей со стейкхолдерами (налоговые органы, общество в целом, бизнес-партнеры и т.д.) характеризуется участием в профессиональных объединениях, партнерствах, ассоциациях, уровнем развития корпоративной и социальной ответственности в компании (по мнению стейкхолдеров).

Таблица 7

Показатели оценки вклада социального капитала в создание ценности компании

\begin{tabular}{|l|l|l|l|}
\hline Факторы успеха & \multicolumn{3}{|c|}{ Показатели } \\
\cline { 2 - 4 } $\begin{array}{l}\text { использования } \\
\text { социального капитала }\end{array}$ & $\begin{array}{l}\text { Управленческая } \\
\text { эффективность }\end{array}$ & $\begin{array}{l}\text { Экономическая } \\
\text { эффективность }\end{array}$ & $\begin{array}{l}\text { Потенциал } \\
\text { развития }\end{array}$ \\
\hline Конкурентоспособность & Эффективность & & Уровень \\
\hline
\end{tabular}




\begin{tabular}{|l|l|l|l|}
\hline & $\begin{array}{l}\text { управления } \\
\text { брендом, уровень } \\
\text { качества по } \\
\text { сравнению с } \\
\text { конкурентами, по } \\
\text { мнению } \\
\text { потребителей }\end{array}$ & $\begin{array}{l}\text { положительной } \\
\text { информации о } \\
\text { компании в прессе }\end{array}$ \\
\hline Надежность партнера & $\begin{array}{l}\text { Репутация как } \\
\text { коммерческого } \\
\text { партнера, частота } \\
\text { срывов и задержек } \\
\text { поставок }\end{array}$ & $\begin{array}{l}\text { Доля затрат, } \\
\text { возникших из-за } \\
\text { срывов или } \\
\text { заджек поставок, } \\
\text { выручке, уровень } \\
\text { зависимости от } \\
\text { поставщика }\end{array}$ & $\begin{array}{l}\text { Вовлеченность } \\
\text { помпании в бизес }\end{array}$ \\
\hline $\begin{array}{l}\text { Налаженность связей со } \\
\text { стейкхолдерами }\end{array}$ & $\begin{array}{l}\text { Уровень развития } \\
\text { корпоративной и } \\
\text { социальной } \\
\text { ответственности }\end{array}$ & $\begin{array}{l}\text { Важность } \\
\text { вступления } \\
\text { компании в } \\
\text { престижный союз, } \\
\text { ассоциацию }\end{array}$ \\
\hline
\end{tabular}

После определения всех показателей необходимо оценить вклад НМА в создание ценности компании. Для этого строятся рейтинговые шкалы по каждому параметру классификации показателей.

Применяемые обозначения в рейтинговой шкале напоминают принятые обозначения в системе рейтингов агентства $\mathrm{S} \& \mathrm{P}$, и таким образом определяется, насколько ценны НMA для компании с точки зрения их вклада в достижение поставленных перед компанией целей, возможностей дальнейшего ее развития и влияния на экономические показатели.

Ниже представлено объяснение присваивания того или иного рейтинга трем группам показателей [Allee, 2008]:

- АAА - самая высокая степень эффективности использования ИК, практически по всем показателям компания получила в среднем 10 баллов.

- АА - очень высокая степень эффективности, средний балл по всем показателям должен быть 9-10.

- А - высокая степень эффективности, средний балл по всем показателям в результате опроса - 8-9.

- $\mathrm{BBB} \mathrm{-} \mathrm{эффективность} \mathrm{выше} \mathrm{средней} \mathrm{(средний} \mathrm{балл} \mathrm{-} \mathrm{7-8),} \mathrm{но} \mathrm{необходимо}$ пристальное внимание к тем параметрам, где, по мнению респондентов, средний балл ниже 8.

- $\mathrm{BB}$ - эффективность средняя, необходимо принять меры для повышения вклада ИК в создание ценности компании.

- $\mathrm{B}$ - эффективность ниже средней, средний балл по некоторым показателям - 6-7.

- ССС - низкая эффективность (средний балл -5-6).

- $\mathrm{CC} \mathrm{-} \mathrm{очень} \mathrm{низкая} \mathrm{эффективность} \mathrm{использования} \mathrm{ИК} \mathrm{(средний} \mathrm{балл} \mathrm{-} \mathrm{4-5),}$ менеджменту компании необходимо разобраться в причинах такой ситуации и искать пути выхода из нее.

- С - эффективность крайне низкая, большинство показателей получили 3-4 балла, необходимы срочные серьезные управленческие меры по улучшению ситуации.

- D - данного вида актива не существует в компании, или она не подозревает о его существовании, а следовательно, данные активы не приносят никакого вклада в создание ценности в компании, отсутствие какой-либо эффективности (средний балл $-1-3)$.

Данные рейтинги будут получены для отдельных элементов ИК, а общий рейтинг 
можно построить на основании информации о структуре ИК и придания соответствующих весов составляющим ИК.

Кроме того, для анализа экономической эффективности не используются рейтинги как таковые, изучаются изменения показателей во времени, а затем, для более полного анализа ситуации, менеджеры могут связывать те рейтинги, которые они получили, с количественными данными.

Таким образом, на стратегическом уровне общим результатом проведения такой рейтинговой оценки должна стать схема 1, приведенная далее в работе, где первый рейтинг характеризует показатели управленческой эффективности, а второй - показатели роста и развития.

На операционном уровне должна быть составлена рейтинговая шкала по критическим факторам успеха использования ИК, что позволит понять, из-за чего реально у компании проблемы и в каких сферах должны произойти изменения, чтобы повысился вклад нематериальных активов компании в создание ценности.

\section{Область применения системы показателей для оценки вклада ИК в создание ценности в компании и ограничения по ее использованию}

Полученная система решает сразу несколько задач:

1. Позволяет визуализировать структуру интеллектуального капитала.

2. Определяет взаимосвязи между источниками создания ценности в компании и отдельными составляющими интеллектуального капитала.

3. Классифицирует показатели на показатели экономической и управленческой эффективности и роста и развития организации.

4. Строит систему рейтингов, оценивающих вклад ИК в создание ценности компании.

5. Выявляет наиболее значимые для компании виды НМА.

Следует отметить, что данная система показателей для оценки вклада ИК в ценность компании является достаточно стандартизированной для того, чтобы принятые рейтинги эффективности могли быть использованы для сравнения двух компаний из одной отрасли. К тому же данная система органично впишется в систему принятия решений, направленных на повышение ценности компании. Например, компания может сначала построить стратегическую карту, а затем (в зависимости от расставленных приоритетов в компании), оценить вклад ИК в достижение поставленных целей, используя данную систему показателей.

Но несмотря на присущие ей достоинства, у разработанной системы показателей существуют и недостатки:

1. Разработка данной системы требует временных затрат, так как необходим постоянный мониторинг показателей, многие из которых являются нефинансовыми (это возможно только при наличии обратной связи с клиентами, партнерами, сотрудниками, проведении регулярной оценки качества и т.п.).

2. Внедрение данной системы оценки вклада ИК в создание ценности в компании, исходя из предыдущего пункта, будет оправданно по затратам для крупных и средних компаний. Для мелких компаний провести такие измерения будет достаточно трудно.

3. При присвоении рейтингов, определении весов существует достаточная доля субъективизма, которую можно преодолеть лишь посредством расширения круга участников проведения измерений, а также включая представителей, занимающих разные позиции и выполняющие разные роли в компании.

4. Данная система не отвечает на вопрос, что компания должна делать, но достаточно точно определяет те сферы, в которых у компании существуют проблемы.

5. Некоторые показатели кажутся достаточно абстрактными (например, репутация компании как коммерческого партнера), но именно в этом заключается основная проблема всех нефинансовых показателей, и чтобы ее решить, те, кто проводят 
измерения, должны дать четкие определения этим показателям, а затем будет легче понять, какую информацию от респондента необходимо получить для измерения показателя.

6. Из-за стандартизации проводимого интервью одни и те же вопросы задаются разным клиентам и партнерам, хотя уровень отношений с компанией у них может варьироваться. Но можно в таких интервью оставлять право за клиентом дополнять некоторые ответы на вопросы, и если это возможно, то получать больше информации о стейкхолдере (размер компании, как долго сотрудничает с нашей компанией и т.д.) или не делать опрос анонимным. Но это потребует больше временных затрат на анализ информации, поэтому за компанией остается право выбора: принять это ограничение или стараться минимизировать его влияние.

При создании системы показателей оценки вклада ИК в создание ценности в компании учитывалось то, что данная система должна органично вписываться в систему принятия решений, направленных на повышение ценности компании, а также давать реалистичные и достоверные результаты.

\section{Заключение}

Таким образом, в данной работе представлена система показателей оценки вклада в создание ценности компании, которая отвечает принципам достоверности и реалистичности результатов, надежности и связанности с созданием ценности в организации, а также служит основой для определения управленческой и экономической эффективности использования HMA.

Перечисленные выше свойства разработанной системы достигаются за счет определения ключевых драйверов создания ценности; определения взаимосвязи между драйверами создания ценности и ключевыми составляющими ИК; осуществления отбора показателей по заранее определенным категориям НМА, которые связаны с созданием ценности в компании; деление этих показателей на показатели управленческой и экономической эффективности, потенциала роста и развития и определение целевых значений по каждому показателю; построение рейтинговых шкал и определение рейтинга по каждому параметру эффективности для каждой составляющей ИК.

Кроме этого, полученная модель позволяет визуализировать структуру интеллектуального капитала, определить взаимосвязи между источниками создания ценности в компании и отдельными составляющими, построить систему рейтингов эффективности использования ИК, которая может служить ориентиром для менеджеров при проведении анализа существующих проблем в управлении различными составляющими НМА и для повышения их вклада в создание ценности компании.

Несмотря на присущие разработанной системе достоинства, у еe показателей существуют и недостатки: разработка данной системы требует временных затрат, для мелких компаний достаточно трудно будет провести измерения согласно ей, при присвоении рейтингов, определении весов существует значительная доля субъективизма, которая не может быть до конца преодолена.

Кроме того, данная модель не отвечает на вопрос, что компания должна делать, но достаточно точно определяет те сферы, в которых у компании существуют проблемы. Некоторые показатели кажутся достаточно абстрактными (например, репутация компании как коммерческого партнера), но именно в этом заключается основная проблема всех нефинансовых показателей, и чтобы ее решить, те, кто проводят измерения, должны дать четкие определения этим показателям, а затем будет легче понять, какую информацию от респондента необходимо получить для измерения показателя.

Данная модель не лишена некоторых недостатков, свойственных другим многокритериальным моделям, но с точки зрения принятых ранее моделей измерения рассматриваемая в статье система показателей оценки вклада ИК в создание ценности 
компании является достаточно стандартизированной, принятые рейтинги могут служить для сравнения двух близких по структуре ИК компаний. Возможность сравнения ИК двух близких компаний дает несомненное преимущество данной системе показателей перед другими, разработанными ранее.

Дальнейшие исследования в этой области могут быть связаны с проведением сравнения двух компаний из одной отрасли, имеющих различную структуру ИК.

Таким образом, из всего вышесказанного можно сделать вывод, что созданная система показателей отвечает самому важному критерию успешности системы измерения ценности предоставлению менеджменту релевантной информации, позволяющей ему принимать адекватные и своевременные управленческие решения для повышения эффективности и конкурентоспособности компании.

\section{Список литературы}

1. Волков Д.Л., Березинец И.В. Управление ценностью: проблема достоверности бухгалтерских моделей оценивания // Вестник Санкт-Петербургского университета. 2006. Сер. 8. Вып. 4.

2. Волков Д.Л. Управление ценностью: показатели и модели оценки // Российский журнал менеджмента. 2005. Т. 3, № 4. С. 67-76.

3. Гаранина Т.А. Структура интеллектуального капитала: вопросы оценки и эмпирического анализа // Вестник Санкт-Петербургского университета. Серия Менеджмент. 2008. Вып. 1.

4. Ивашковская И.В. Управление стоимостью компании: вызовы российскому менеджменту // Российский журнал менеджмента. 2004. № 4. С. 113-132.

5. Коупленд Т., Коллер Т., Муррин Д. Стоимость компаний: оценка и управление. - 3-е изд., перераб. и доп. / Пер. с англ. М.: ЗАО «Олимп-Бизнес», 2005. С. 166.

6. Удовиченко О.М. Понятие, классификация, измерение и оценка нематериальных активов (объектов) компании: подходы к проблеме. Научные доклады № 13 (R). СПб.: НИИ менеджмента СПбГУ, 2007.

7. Allee, V. (2008), Value network analysis and value conversion of tangible and intangible assets, Journal of Intellectual Capital, 9(1) (2008).

8. Andreou, A., Green, A., and Stankosky, M. (2007), A framework of intangible valuation areas and antecedents, Journal of Intellectual Capital, 8(1) (2007).

9. Ashton, R. (2008), Value-creation models for Value-based management: review, analysis and research directions, Advances in Management Accounting, 16 (2008) 1-62.

10. Green, A., Ryan, J. (2005). A framework of intangible valuation areas (FIVA): Aligning business strategy and intangible assets, Journal of Intellectual Capital, 6(1) (2005) 43.

11. IAS 38. Intangible assets. International Accounting Standarts, 2009.

12. Kaplan, R.S., Norton, D.P. (2005), Measuring the strategic readiness of intangible assets, Harvard Business Review, 82(2) (2005) 52-63.

13. Lev, B. (2001), Intangibles: management, measurement, and reporting, Brookings Institution Press, Washington, D.C.

14. Pike, S., Roos, G., Marr, B. (2005), Strategic management of intangible assets and value drivers in R\&D organizations, R\&D Management, 35 (2) (2005).

15. Stewart Thomas. Intellectual Capital: The New wealth of Organizations. 1997. Doubleday.

16. Volkov, D., Garanina, T. (2007), Intellectual Capital Valuation: Case of Russian Companies. Discussion Paper \#9(E) - 2007. Graduate School of Management, Saint Petersburg State University, St.Petersburg. 